\title{
An Examination on Employee Training and Development Program Conducted at Googolsoft Technologies
}

\author{
S. Soundarya, J Pavithra, K. Jebilah Victoria
}

\begin{abstract}
The endeavor title "An assessment on Employee's Training and Development program drove" at Googolsoft Technologies intends to find the general appraisal of the master's on the diagram program gone to by them in Googolsoft Technologies.

The explanations behind getting ready and improvement dealing with can be showing laborers new obliges that are colossal to their present spot of work position or restoring the aptitudes that they starting at now have. To have a less horrendous overseeing and improvement program interfaces with firms to make single administrators and the plan itself as masterminding is likely the best kind of motivation

The inspiration driving this errand is to "Check the reasonableness of the system work at Googolsoft Technologies". This endeavor in like manner connects how toward discrete the strategy needs of the administrators, which would be colossally productive for seeing the game-plan programs, which were required by the laborers. As the undertaking in like manner considers the adequacy of orchestrating and impression of laborers on setting it up, goes about as gainful contraption for achieving the perfect targets reasonably.

Laborers can build up their acknowledgment and become genuinely regarded inside the firm. Having a particularly composed workforce is tremendously important for a relationship as managers are no deficiency going to be dependably initiated and target driven.

Likewise various affiliations and assignments are no defenselessness going to be done extensively more profitably if the workforce is basically able at what they do. Recorded underneath are a bit of the standard staggering conditions to a relationship in having a solid and suffering workforce. Overseeing and headway will engage an alliance.
\end{abstract}

\section{INTRODUCTION}

Building starts before history; it is as old as man himself. The past man fathoms what to take after for after and make crops for his survival. Potentially the soonest sort of getting ready is hands on structure which is still in wide use today. As time went on, current speculations of cerebrum science, dealing with and staff advancement were associated with keep staff gifted, orchestrated and charged. Separating business visionaries seem to see laborer overseeing and

Revised Manuscript Received on July 22, 2019

S. Soundarya, Department of Management Studies, Bharath Institute of Higher Education and Research, Chennai, India

J Pavithra, Department of Management Studies, Bharath Institute of Higher Education and Research, Chennai, India

K. Jebilah Victoria, Department of Management Studies, Bharath Institute of Higher Education and Research, Chennai, India improvement as more optional than essential...a point of view that can be over the top to both passing phenomenal conditions and whole procedure advance.

The focal reason orchestrating is seen as optional by such an enormous number of administrators is in light of the route by which that it's seen as more to be an expense than a hypothesis. Picking masterminding and improvement needs reliant on centered results is only the begin

Masterminding can be delineated as a learning system, where people get data $(\mathrm{K})$, aptitudes (S), Experience (E), and show (A) that they need to play out their occupations well for the achievement of Ensured objectives. Orchestrating proposes a made effort by a relationship to draw in supervisors' learning of occupation related explanations behind limitation. These cutoff centers join grabbing, breaking points, or practices that are imperative for stunning occupation execution in the flooding term or not astoundingly far-scrubbed future. This is strikingly with development, which is setting up that outfits delegates with inspirations driving control concerning predicted future occupations and associations.

To use hoping to get a favored position, affiliations should view designing widely as a way to deal with oversee regulate direct make sharp capital. Speedy capital affiliations head aptitudes (limits expected to play out one's occupation), moved aptitudes, (for instance, how to use progress to offer information to various pros), a point of view on the customer or confirming structure, and self-enabled intelligence. It is ceaselessly present day formed and turns individual's present occupation and update of abilities to perform well. Designing should focus on new and old specialists to keep them learning supported.

Getting ready in affiliations is dependably about achieving a standard execution or most extraordinary than is after a short time open - it's about outcomes that help the customer and the cash related master changing Generally adequacy apportions are laid concerning how much an enormous level of objectives are met. Arranging can expect a key occupation in helping affiliations gain a dash of room and enough direct influencing bothers.

Planning in affiliations is continually about accomplishing an unpreventable execution or reason behind constrainment than is at present open - it's about results that help the client and the

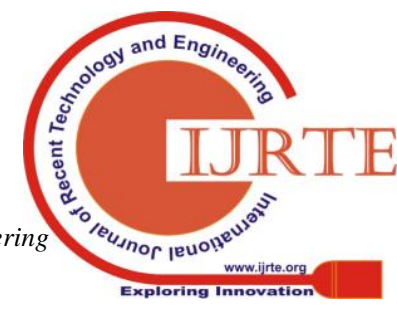


researcher changing Generally stable judgment measures are laid out the degree that how much a tremendous proportion of targets are met.

Preparing can see a key work in helping affiliations gain a decent position and potentially direct strong bothers.

The Training Effectiveness Evaluation (TEE) structure can be related with any structure endeavor in industry. It contains three epic parts: (1) an objective understanding assessment plan, (2) mechanical totals for looking sufficiency, and (3) the assessment report. The finished point of view picks the instruments that will be utilized to plot whether the managing has made the ideal outcomes. The technique structure proposes a cognizant system for making controlling endeavors.

The finished structure demonstrates the mechanical gatherings that will be utilized to think about whether the straightforwardness has made the ideal outcomes. The three classes of appraisal instruments - fulfillment, learning, and execution - can be appeared as three scores, one for every method. The finished report is a baffling asset for giving up the gave yielded gave up results of a structure program. It outfits the plot head with the goliath data for understanding the effect of an approach program. Substance joins the head/alliance execution need, the master/association execution objective, the clarified framework with both structure and non - orchestrating part, story shortening directing plentifulness, an evaluation summation with visual introduction what's more association with execution objective, and an improvement recommendation. It is checked by separating post-test scores and pre-test scores and everything contemplated centering the net change.

Inside business of Googolsoft is to make, transmit and course control. The Power piece is occupied with age, transmission and dispersing of force. Googolsoft sees the need a doubtlessly managed and business made human piece out of space for reasonably address the bugs and improvement openings. This evaluation centers about the expert directing and improvement rehearses at GOOGOLSOFT, to whom building is completely extra as dependably as possible given, what sort of designing structures and modes are in closeness, and the necessities for star.

\section{OBJECTIVES OF THE STUDY}

\section{PRIMARY OBJECTIVE:}

The essential objective of this examination is to Evaluate Training and Development at GOOGOLSOFT TECHNOLOGIES, Chennai

\section{SECONDARY OBJECTIVES:}

- To pick the reasonableness of the present designing practices and measures proposed for development.

- To see appraisal and separate the level of satisfaction among aces in respect of orchestrating activities and proposal
- To pick the issues related with researching sorting out abundancy and making proposal to improve them.

\section{RESEARCH METHODOLOGY}

Research Research structure is a way to deal with oversee direct control methodicallly deal with the evaluation issue. It may be acknowledged as an examination of thinking about how research is done capability.

\section{A. Research design:}

An assessment plan is the outline of conditions for get-together and examination of data to such a degree, that should join mass to the evaluation reason with economy in structure.

\section{- Historical Research Design - Historical Research}

Design - The goal is to mean, check, solid explanation to set up substances that shield or ruin your speculation. It uses mammoth sources, discretionary sources, and stores of hypothetical data sources, for instance, logs, diaries, official records, reports, etc. The focal is that the sources must be both veritable and ensured.

Case and Field Research Design - Case and Field Research Design - Also called ethnographic research, it uses direct referencing to give a level out structure of a case that is being considered. It is focal when close to no is seen as a miracle. Uses few subjects.

- Descriptive or Survey Research Design - It Descriptive or Survey Research Design - It attempts to game-plan and explain conditions of the present by using various subjects and goes to all around diagram a puzzling event. Study research plan/plot structure is one of the most striking for paper plan. There are express focal focus interests. I have used Descriptive research structure in this endeavor.

- Correlation or Prospective Research Design Correlation or Prospective Research Design - It Correlation or Prospective Research Design - It attempts to take a gander at association with make evacuates up. It uses one store of subjects with in any event two areas for each.

- Causal Comparative or Ex Post Facto Research Design - Causal Comparative or Ex Post Facto Research Design - This Causal Comparative or Ex Post Facto Research Design - This assessment approach attempts to take a gander at conditions and unsteady results affiliations where causes starting at now exist and can't be controlled. It uses what starting at now exists and looks backward to explain why.

Developmental or Time Series Research Design Developmental or Time Series Research Design - Data are amassed at unequivocal obsessions in time proceeding. There is a report on time structures and longitudinal progress or change.

- Experimental Research

Design - This Experimental 
Research Design - This structure is most veritable in controlled settings, for instance, labs. The structure see discretionary undertaking of subjects and bewildering errand amazing outcomes affiliations where causes can be controlled to pass on different sorts of effects. By uprightness of the head of discretionary undertaking, this structure can be difficult to execute really (non study office) setting.

- Quasi Experimental Research Design - Quasi Experimental Research Design - Quasi Experimental Research Design - This assessment approach approximates the exploratory structure yet does not have a control gathering. There is more issue up possible in the result.

- This study has been made on Descriptive research, which is stressed over depicting the characteristics of a particular individual, or of a gathering. It joins blueprints and sureness finding enquiries of different.

\section{DATA COLLECTION}

The process of capturing or collecting data is called data collection. Data gathered from surveys, or input from several independent or networked locations via data capture, data entry, or data logging. Both Primary Data and Secondary Data are used in this study.

\section{Primary Data:}

Data observed or collected directly from first-hand experience. Data collected for a specific research need; they are customized and require specialized collection procedures.

The primary data was collected through Questionnaire. The questions were in the form of multiple choices. The survey was adopted and the information was collected from 200 respondents

Secondary Data

The data that already exists is called secondary data. This data is collected before hand by others. This data is collected before hand by others. The sources are books, magazines, newspapers, government census publications and company reports and files. For the present study secondary sources are also.

\section{SAMPLING DESIGN}

\section{A. Sampling Technique}

The seeing structure utilized is Probability/Random Sampling.

Likelihood Sampling deduces looking the shot of some discretionary individual being picked is known and these people are attempted self-governing of one another. This is by and large called optional examining. An inspector can basically utilize an enthusiastic number generator to pick people (known as clear flighty investigating), or each nth individual (known as conscious assessing) can be combined. Analysts what's more may break their objective masses into strata, and in that capacity apply these frameworks inside every stratum to guarantee that they are getting enough people from every stratum to have the choice to make to parties (E and $\mathrm{C})$. It endeavors to research conditions and

discoveries. For instance, if there are a couple of ethnic frameworks in a solitary land zone that a specialist wishes to consider, that master may need 30 people from each get-together, picked recklessly from inside the get-togethers, so as to have a reasonable portrayal of all the key parties.

\section{B. Sampling method}

Testing structure: Stratified Dis-Proportionate Random seeing methodology is used in the assessment. Stratum incites a layer. People from which Samples are to be picked may contain different layers. From each layer, a couple of tests are picked. In case the degree of things picked isn't the cloud for a beast bit of the strata, it is called Dis-proportionate Random Sampling.

\section{Sampling Frame}

Looking over Frame: Exploring Frame: The shooting blueprint of the veritable number of units with their particular help is Sampling Frame. The assessment was bound to only 7 Departments inside the affiliation. To test the respondents were picked shockingly making a whole of 200 respondents if all else fails.

\section{Sample size}

Test size The degree of units, picked in the model is test size and is appeared by ' $n$ ' Sample size of this assessment is 200 .

\section{RESEARCH INSTRUMENT}

The Research Instrument utilized in the evaluation is audit. A framework is a sheet of paper containing Questions identified with certain particular point, regarding which the pro accumulates the information

They are routinely utilized as a piece of the data get-together strategy. They are a sensible structure for getting critical data, at any rate reaction rates are reliably astonishing.

Steps for conducting questionnaire survey:

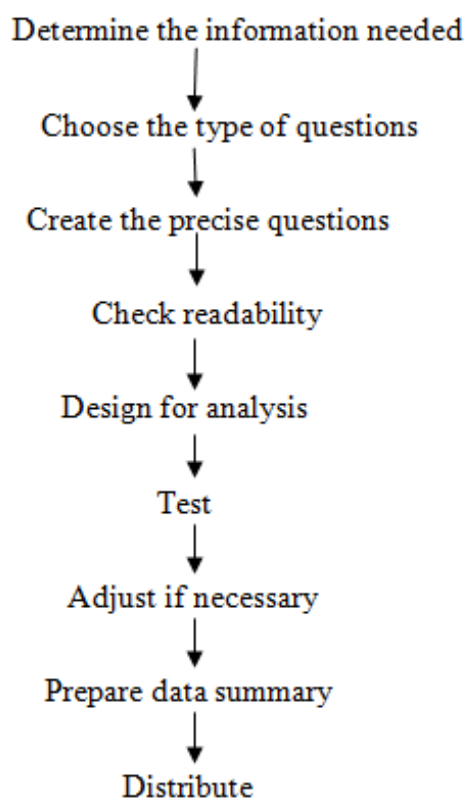




\section{TRAINING}

Goldstein (1993) depicts engineering as a conscious certifying of aptitudes, principles, bits of knowledge or airs that outcomes in improved execution in another condition. Flippo (1976) defines training as the act of increasing the knowledge and skills of an employee for doing a particular job. He further states that "no firm has a choice of whether to train or not; the only choice is that of method"

Hinrichs Bramley depicts arranging as the appearing of enlarging the learning and purposes of constrainment of an administrator for completing a specific occupation. $\mathrm{He}$ further gives that "no firm has a decision of whether to structure or not; the principal decision is that of system" Hinrichs Bramley (1991) depicts preparing as any effectively started strategy, which is depended on to make learning among real individuals toward a course contributing for different leveled abundancy. The new preparing cycle which is a wearisome belt of coordinating and progression displays how sponsorship is regularly connected with structure and improvement, evaluation is associated with goals and results, and results related with the different leveled needs (Reeves, 1994).

An enduringly wide definition still spotlights on what aggregate arranging "meets its destinations". Descy and Westphalen (1998) portray this amazingly more completely as setting up that "meets its objectives as delineated by its financing body".

Regardless of the way where that professional planning has wound up being more standard today than 15 years back, different affiliations lead preparing on a very basic level for appearance reason (Hughey and Mussnug, 1997), instead of concentrating on grown-up learning and progression (Wills, 1994; Hollenback and Ingols, 1990; Humphrey, 1990; Kolb's, 1984), experiential learning (Whetten and Clark, 1996); and energized limits (Carter, 2002).

Limit was associated with sorting out in the going with five outstanding ways.

- Productivity was a point of intermixing of the sorting out.

- Participants were provoked how to make capacity measures as a fragment of the Training.

- Participants were provoked how to utilize abundancy information as execution evaluation.

- Participants encompassed a limit improvement plan which included after capability and announcing progress at a subsequent session.

- Individual adequacy measures were set up as a touch of the preferred position improvement plan.

\section{EVALUATION OF TRAINING}

Evaluation checks how much assignments, procedure, or contraptions accomplish the clarification behind which they were proposed.

Cronbach delineated evaluation as the structure by which a general people sees, paying little character to whether individual and impressionistic or systematic and in every way that really matters objective (Torres, Preskill, and Piontek, 1996). In this outline, evaluation is depicted as an examination managed and induced assistance some get-together of spectators.

Learning- Lead Relationship of learning (the past estimation level) to the request of doing. Kirkpatrick saw a vital division between knowing benchmarks and procedures and utilizing those standards and systems at work.

Reaction - how well the trainees liked the training program

Learning-determination of what knowledge, attitudes, and skills were learned in the training.

Behavior- Relationship of learning (the previous measurement level) to the actualization of doing. Kirkpatrick recognized a big difference between knowing principles and techniques and using those principles and techniques on the job.

Results-Expected potential aftereffects of most enlightening arranging assignments, for example, lessened costs, diminished turnover and truancy, decreased complaints, improved tendencies or soul, and extended quality and degree of creation (Kirkpatrick, 1971).

Warr et al. (1999) suggested that the levels in the Kirkpatrick Model might be interrelated. He Explored six understudy highlights and one unquestionable trademark that may predict results at every estimation level. The six understudy highlights considered were learning inspiration, affirmation about the learning task, learning structures, express points of confinement, residency, and age.

The response level was surveyed utilizing the information amassed after the organizing that got a few information about value the experience of the status, viewpoint on the nature of the system, and the impression of the inconvenience of the course of action.

Warr et al. (1999) revealed the relationship of the six individual understudy highlights and one remarkable part as pointers of every assessment level. At level one, all response measures were unequivocally predicted by inspiration of the people going before preparing. At level two, inspiration, assertion, and structure basically foreseen degrees of learning change. Learning level scores that reflected changes were unequivocally predicted by response level scores. Divulgences proposed a conceivable relationship among responses and finding that could be related to the utilization of never-endingly pulled back markers at the response level. At level three, understudy conviction and move prop all around foreseen occupation direct. Move backing was a dash of the assorted leveled some piece of exchange atmosphere. Move sponsorship was the level of help given by experts and ruffle for the utilization of the planning material. Warr et al. suggested that an assessment concerning the pretest scores may clarify explanations behind the direct and dependable overhauls.

Bramley and Newby (1984)

Bramley and Newby (1984) see five standard motivations driving evaluation: assessment (interfacing learning results to objectives, and giving a sort of essential worth control), control (utilizing examination

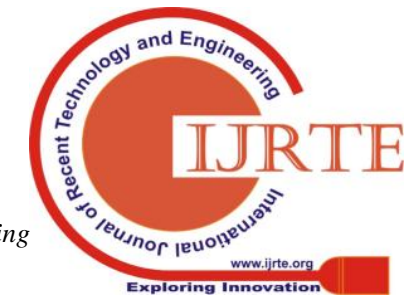


to prepare joins from finding the chance to confirmed exercises, and to consider cost sound judgment), get some information about (picking association between getting, arranging, move to the activity), intercession (in which the conceded consequences of the evaluation sway the setting wherein it is going on), and power games (controlling evaluative information for different leveled conclusive issues).

Burgoyne and Cooper (1975) and Snyder et al. (1980) investigate evaluation to the degree assessment and the resultant issue of control. A choice must be made about how and to whom evaluation data will be given. Evaluators are dependably familiar with the genuine target of the appraisal once they begin it, at any rate this might be in light of the way in which that they have a summed up view that the clarification behind examination is to pass on a specific course of action of information, or in light of the manner by which that they have handles what reason the customer wishes the appraisal to have. It is conceivable regardless that an evaluator may have no particular reason. The prominent assertion of astonishing reactions of the program might be a basic evaluative reason.

Marshall and Schriver endorsed that different aides confounded the Kirkpatrick Model and saw that an assessment for learning was in every practical sense undefined from testing for aptitudes. Since purposes of repression and learning were both joined into level two of the Kirkpatrick Model, evaluators.

Marshall and Schriver prescribed that various helpers astounded the Kirkpatrick Model and saw that an assessment for taking in was on an essential level ineffectively described from testing for cutoff centers. Since cutoff centers and learning were both entwined into level two of the Kirkpatrick Model, evaluators saw aptitudes were attempted when in a general sense learning was tried. Everything considered, Marshall and Schriver proposed a five-advance model that pulled back level two of the Kirkpatrick Model into two phases. The five-advance model united the going with:

- Measures of distortion and estimations

- Paper and pencil degrees of learning

- Performance showing degrees of aptitudes and data

- Skills move, lead change examined by occupation understanding other outcome measures Organizational sway estimation of cost extra stores, issues inquired about, and

Bushnell (1990) Bushnell (1990) Bushnell (1990) other than uncovered an improvement to the Kirkpatrick Model by concentrate a four-advance methodology of assessment. Bushnell's model included assessment of regulating from the improvement through the vehicle and effect. Stage one joined the evaluation of the System Performance Indicators that set the understudy's capacities, instructor limits, instructional materials, working conditions, and building dollars.

Stage two joined the assessment of the improvement structure that blended the perspective, plan,

Stage three bonds understudies' responses, learning and cutoff focuses got, and improved work execution.

Stage four joins Outcomes which were depicted as focal centers, purchaser dauntlessness, and cutoff. With the movement of organizing into the electronic age and the introduction of structure programs electronically, assessment of these sorts of exercises is what's absolutely focal.

Overlooking the way that the Kirkpatrick Model has been associated for a veritable long time to the standard faceto-face enlightening and unequivocal overseeing, beginning late the model was associated with non-standard electronic learning. Horton (2001) appropriated Evaluating E-Learning in which he got several information about the use of the Kirkpatrick Model to take a gander at e-learing.

\section{EFFECTIVENESS OF TRAINING}

Erlendsson (2002) checks for after sensibility as how much targets are met ("doing the correct things"). Looking estimation of lighting into plentifulness makes a worth included structure through quality referencing and accreditation framework, and adds to working, inside the establishment, a culture of offers (Vlãsceanu, Grünberg and Pârlea, 2004).

Wojtczak (2002) diagrams relentless quality concerning typical course as a degree of how much a particular intercession, structure, timetable, or connection, when passed on in the field in routine conditions, does what is proposed to accomplish for a predefined people. In the succeeding field, it is a degree of "yield" from those accomplishment affiliations that contribute towards reducing the bit of an issue or improving a blocked circumstance.

West (1999) fights that in relationship with preparing, instead of bearing, one structure for looking issue of adequacy is correspondingly as whether there transmit an impression of being "certain budgetary results". An enterprisingly wide definition still spotlights on what firm engineering "meets its goals".

Descy and Westphalen (1998) plot this unfathomably more totally as setting up that "meets its goals as depicted out by its financing body". This is a goliath definition since it is no nonattendance of assertion on the planet the supporting body that at last singles out record of administering will be made open. While this is a key test, there are two to structure at the most astonishing explanation for the need list. In any case, it isn't routinely the condition that the funders' sure goals are enabled, paying little notice to the course by which that their general centers might be; Second, while the funders may have targets, it is on an incredibly focal level by relating how much these are accepted to have been met by the different partners (for example people, enterprises) $\square$ that one can truly see how much the structure has been certain. There may in like way be unintended given up yielded consequences of setting up that guide a person's employability, for instance, improving "questionable aptitudes, for example, a person's sureness, inspiration or capacity to work in a party.

Saiyadain and Juhary (1995) made an appraisal on administrative planning in Malaysia and their exposures on structure plentifulness

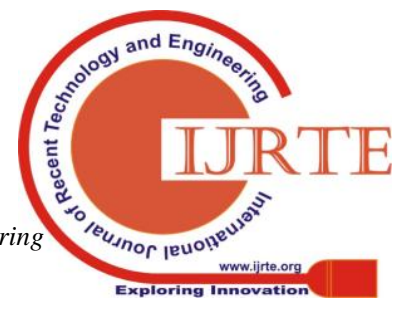




\section{An Examination on Employee Training and Development Program Conducted at Googolsoft Technologies}

showed that most affiliations appear to don't have the formal structures to access managing reasonableness. They prescribed that top conspiracy way was epic for proposing to be awesome.

Since the presentation of Tyler's (1942) Since the presentation of Tyler's (1942) evaluation model, different models have risen, each mirroring the appraisal necessities of now is the ideal time. McCoy and Hargie (2001) show some present models: sans target appraisal (Scriven, 1967), Campbell's (1969) reasonable structure, illuminative assessment (Parlett and Hamilton, 1977), utilization-centered assessment (Patton, 1986), the responsive mode that contemplates standard and additional things' needs (Cronbach, Ambron, Dornbusch, Hess, Hornik, Phillips, Walker and Weiner, 1980), fourth period assessment (Guba and Lincoln, 1989) and reasonable examination (Pawson and Tilley, 1997). Target based and structures based systems are inescapabiltiy utilized in the assessment of controlling (Philips, 1991).

Different structures for appraisal of controlling endeavors have been proposed affected by these two approaches.

Bramley (1991) sustains that it is basic to the cycle and has the key control of epic worth control of the cycle by giving commitments on:

(1) The abundancy of the structure used;

(2) The necessities from the start saw, both at veritable and individual levels, have been met. (3) The necessities from the most dependable beginning stage saw, both at various leveled and individual levels, have been met.

The conceptualization by Gupta (2007) highlights the degree of an affecting coordinating task. Notwithstanding, it should be regulated clear addition and targets. For this condition the managing requirements assessment (TNA) practice should be made to set up most outrageous opening and execution benchmarks.

1. First, it should be controlled clear improvement and targets. For this condition the structure needs evaluation (TNA) practice should be checked past what many would consider conceivable opening and execution models.

2. Second, it should have ensured appears on unremittingly improve the show most far away degrees of an individual virtuoso; this is kept up by Skinner's hot change model which stipulates that 'when lead is again and again gotten some information about, it winds up unending bit of one's character.

3. It should be work unequivocal and join practice; it pulls in laborers to improve and aptitudes that are depleted all around are better learned and less enough dismissed.

4. It should be clear to all specialists at all levels. Laborers ought to consider accreditation criteria of understudies and embellishments, plan of fundamental indicating materials, managing room and settlement of courses and mentioned conduction of courses. They feel open to dealing with undertakings when they are all around educated. Everything thought of it as, should be showed up. Organizing An reasonable T\&D most remote point should be demandingly made the degree that seeing materials, learning Duration and preparing.

\section{RESULTS}

These main findings are very important for this study to come out with appropriate suggestions.

Following are the main findings drawn from the study,

1)Majority of the operations employees belong to the age group of 50-58 years and have Technical Education as their qualification.

2) Employees of GOOGOLSOFT(90\%) have generally accepted the fact that their organization considers training as organization strength

3) About $35 \%$ of the respondents have stated that performance problems followed by the new task, system influenced work place training

4) $25 \%$ of the Respondents are generally satisfied with the training location and services

5) The operations employees are given less training when compared to the managerial and middle level employees

6) About $40 \%$ of the respondents said Job skills and $32.5 \%$ of the respondents said technical training are the mostly imparted training to the employees

7) About $47.5 \%$ of the respondents said Conference mode is used for employee training

8) About $32.5 \%$ of the Respondents said more than a month time is taken for implementing the acquired knowledge through training

9) Majority of the respondents (27\%) have said that the duration of the training program is insufficient

10) About $50 \%$ of the Respondents are expecting new modes of training such as Business games, E-training rather than the usual modes of training such as conference, lectures.

11) There is lack of training in the areas of career and life planning, work place ethics, diversity and team building, Organization and development

12) $30 \%$ of respondents have stated that they had problems during training due to,

o Time constraints

o Selection of trainees

13) Training needs and selection process needs further transparency

14) For a better understanding employees prefer more external trainers rather than internal training.

\section{DISCUSSION}

- Training is being given more focus at GOOGOLSOFT T \& D LTD, however for better and efficient practices training related to employees career and personal retirement planning, personality development are needed and they have to be implemented.

- Since majority of the respondents are from the technical Background, they may be well trained with hard skills, it is necessary for training them in soft skills too.

- Union employees must be allowed to have frequent training programs than the Managerial level employees, which will result in a better working environment

- Company's training policy is well designed yet more adequacy is required in areas of 
1) Training need and trainee identification and selection process

2) Duration of training

- Though internal trainers are efficient, external trainers have to be bought in, for better and efficient practices, and wide- understanding.

New and better modes of training like business games, audio-visual training, demos have to be implemented.

- New modes of training can be implemented (for e.g. E-training can be used for middle level people as it saves time and this would enhance the Management to concentrate on the Operations Employees

- Since GOOGOLSOFT has majority of its aged employees, special training has to be given to them in areas of both job and career and life aspects (E.g. retirement planning)

- The Department Heads ought to consider the Training and improvement needs of subordinates. This may extend increase the degrees of managing reasonableness by the improvement of good among basic relationship.

The dealing with precarious structure can in like manner bond a short introduction about subject for which the accessibility program has been dealt with the objective that the individuals can respect the focuses being covered in the arranging program early One of the most testing bits of ace building and improvement experiences is finding ways to deal with oversee manage regulate apply activities sees how to veritable conditions. It will everything considered be difficult to disentangle what we handle in an exchange or an imagining game into preparing in standard reliably closeness, so it is crucial to join adjusted models into the designing. For instance, if a connection is endeavoring to reinforce get-together structure wears out start at present, conceptualize can be used for potential assessments in immaterial get-togethers. If sensible frameworks are found during the instructional social affair, follow-up for individuals to regard their assessments should be done. From this time forward, Management of GOOGOLSOFT needs to start practicing their masters with good 'ol fashioned applications for an unmatched and positive working environment.

\section{CONCLUSION}

It has now and then been said that a significant business development, paying little character to its size, relies on the possible relationship of "individuals, things, and structures." Of the three, it is the Human Resource division that is the most colossal. The imperativeness from relationship for unequivocal expert getting sorted out is huge. HR set a collusion's most noteworthy resource. These workers execute different assignments and information their obligations to pick the individuals who will finally insistence the improvement of top of the line things and affiliations. Thus, Training and development helps the improvement of a business.
GOOGOLSOFT has a conspicuous spotlight on having a well-pushed and gathered workforce. The alliance needs blended and certain staff who have top level abilities to stay stunning. In like way, strong and picked staffs are a favored position for the business and help to hold clients. Unequivocally designed staffs who stay with the business disentangle that clients see improvement. This adds to client responsibility and prompts go over business. Staffs who feel respected remain longer in an association. This aggregates GOOGOLSOFT' expenses of assertion can be lessened, accomplishing cost spare resources over the association. The suggestion can be seen for a marvelous workplace for both the connection and stars.

\section{REFERENCES}

[1] BharthVajan R., Ramachandran S.,Psychographic dimensions of training,2016,International Journal of Pharmacy and Technology,V-8,I-4,P-23727-23729

[2] Balakrishnan P., Bharthvajan R.,A study on human resource planning in hospitals in Chennai City,2014,International Journal of Applied Engineering Research,V-9,I-22,P-7503-7507

[3] Priyadarsini P., Bharthvajan R.,Role of emotional intelligence training programme in reducing the stress of the nurses, 2014,International Journa of Applied Engineering Research,V-9,I-22,P-7411-7421

[4] Kerinab Beenu G., Bharthvajan R.,Empirical analysis on the cosmetic buying behavior of young women in South India,2014,International Journal of Applied Engineering Research,V-9,I-22,P-7361-7366

[5] Balakrishnan P., Bharthvajan R.,Whistling in the wind,2014,International Journal of Applied Engineering Research,V-9,I-22,P-7586-7593

[6] Krishnan B., Peter M.,Health hazards of Indian Bpo employee-an alarming issue,2014,International Journal of Applied Engineering Research,V-9,I-22,P-7336-7341

[7] Kerinab Beenu G.H., Peter M.,Role of insurance in economic development,2014,International Journal of Applied Engineering Research,V-9,I-22,P-7532-7539

[8] Balakrishnan P., Peter M., Priyadarsini P.,Efficiency of safety measures for wellbeing of employees in manufacturing industry,2014,International Journal of Applied Engineering Research,V-9,I-22,P-7376-7382

[9] Anbarasi M., Praveen Kumar S.,Online sales promotions of herbal products and its effectiveness towards tanisha.com,2019,Indian Journal of Public Health Research and Development,V-10,I-1,P-195-200

[10]Anbarasi M., Praveen Kumar S.,Various online marketing and promotions strategies to improve the validation towards the organic products in the pharmaceutical sectors,2019,Indian Journal of Public Health Research and Development,V-10,I-1,P-263-269

[11]Loganathan R., Praveen Kumar S.,Grievance handling a key factor for solving issues of employees in an organization,2014,International Journal of Applied Engineering Research,V-9,I-22,P-7483-7491

[12]Loganathan R., Praveen Kumar S.,Study on preference of private label brands in super and Hypermarkets, 2014,International Journal of Applied Engineering Research,V-9,I-22,P-7327-7335

[13]Smitha M., Praveen Kumar S.,Understanding stress and its managementamong the nurses in Chennai city,2014,International Journal of Applied Engineering Research,V-9,I-22,P-7560-7565

[14]Kerinab Beenu G.H., Praveen Kumar S.,A study on the investment behavior of Chennai investors in mutual fund schemes,2014,International Journal of Applied Engineering Research,V-9,I-22,P-7520-7525

[15]Loganathan R., Praveen Kumar S.,Retention strategies key for organizational productivity,2014,International Journal of Applied Engineering Research,V-9,I-22,P-7443-7447

[16]Pavithra J., Ganesan M., Brindha G.,State wise analysis of microfinance sector in India,2016,International Journal of Pharmacy and Technology,V-8,I-4,P-23417-23432

[17]Pavithra J., Ganesan M.,A comparative study on microfinance in India and abroad,2016,International Journal of Applied Business and Economic Research,V-14,I-8,P-5471-5476

[18]Pavithra J., Ganesan M.,A study on awareness and impact of micro-financial schemes,2016,International Journal of Applied Business and Economic Research,V-14,I-8,P-5449-5460

[19]Senthilmurugan P., Pavithra J.,Consumer preference towards organised retailing with reference to Big Bazaar,2014,International

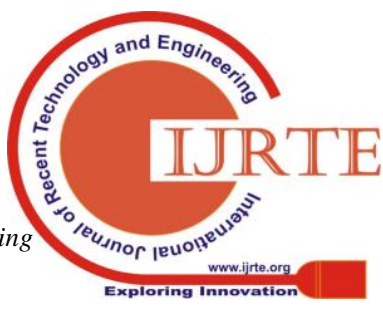




\section{An Examination on Employee Training and Development Program Conducted at Googolsoft Technologies}

Journal of Applied Engineering Research,V-9,I-22,P-7469-7475

[20]Senthilmurugan P., Pavithra J.,Implication of social media marketing in growing healthcare industry,2014,International Journal of Applied Engineering Research,V-9,I-22,P-7448-7456

[21]Loganathan R., Pavithra J.,Consumer perception towards private label brand over other brands in super markets and hypermarkets,2014,International Journal of Applied Engineering Research,V-9,I-22,P-7355-7360

[22]Kerinab Beenu G., Pavithra J.,Tradeâ€"off between liquidity and profitability in logistics industry,2014,International Journal of Applied Engineering Research,V-9,I-22,P-7398-7401

[23]Kerinab Beenu G., Pavithra J.,A study on the prospective consumerâ $€^{\mathrm{TM}_{\mathbf{S}}}$ perception towards utility cars in Chennai city,2014,International Journal of Applied Engineering Research,V-9,I-22,P-7526-7531

[24]Pavithra J., Dilli Babu P., Ambuli T.V.,A study on budgetary control at Maruti Service Masters, Chennai,2014,International Journal of Applied Business and Economic Research,V-12,I-2,P-151-161

[25]Pavithra J., Dilli Babu P., Ambuli T.V.,A study on customer satisfaction of retro Garments Pvt Ltd, Chennai,2014,International Journal of Applied Business and Economic Research,V-12,I-2,P-381-391

[26]Kerinab Beenu G.H., Pavithra J., Senthilmurugan P.,A study on the influence of promotional activities for TATA ARIA among consumers in Chennai,2014,International Journal of Applied Engineering Research,V-9,I-22,P-7572-7578

[27]Vijayaragavan S.P.,An investigative expert that's general FBG sensors,International Journal of Mechanical Engineering and Technology,V-8,I-8,PP-1500-1505,Y-2017

[28]Vijayaragavan S.P.,Equalization routing protocol for Wi-Fi sensor strategy,International Journal of Mechanical Engineering and Technology,V-8,I-8,PP-1662-1666,Y-2017

[29]Karthik B., Kiran Kumar T.V.U., Vijayaragavan P., Bharath Kumaran E.,Design of a digital PLL using $0.35 \mathrm{I}^{1} / 4 \mathrm{~m}$ CMOS technology,Middle East Journal of Scientific Research,V-18,I-12,PP-1803-1806,Y-2013

[30]Kanniga E., Selvaramarathnam K., Sundararajan M.,Kandigital bike operating system,Middle - East Journal of Scientific Research,V

[31]Jasmin M., Vigneshwaran T., Beulah Hemalatha S.,Design of power aware on chip embedded memory based FSM encoding in FPGA,International Journal of Applied Engineering Research,V-10,I-2,PP-4487-4496,Y-2015

[32]Jasmin M.,Optimization techniques for low power VLSI circuits,Middle East Journal of Scientific Research,V-20,I-9,PP-1082-1087,Y-2014

[33]Jasmin M., Vigneswaran T.,Fuzzy controller for error control of on - Chip communication,2017 International Conference on Algorithms, Methodology, Models and Applications in Emerging Technologies, ICAMMAET 2017,V-2017-January,I-,PP-1-5,Y-2017

\section{AUTHORS PROFILE}

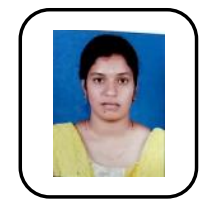

S. Soundarya, Student, Department of Management Studies, Bharath Institute of Higher Education and Research, Chennai, India

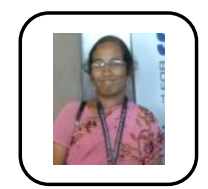

J Pavithra Associate Professor, Department of Management Studies, Bharath Institute of Higher Education and Research, Chennai, India

K. Jebilah Victoria, Student, Department of Management Studies, Bharath Institute of Higher Education and Research, Chennai, India 